\title{
Effect of moisture content of two paddy \\ varieties on the physical and cooked properties of produced rice
}

\section{Efeito do teor de umidade de duas variedades de arroz sobre as propriedades físicas e de cozimento}

\author{
Abeer S. Alhendi ${ }^{1 *}$ (D), Salam H. Al-Rawi ${ }^{1}$ (D), Ahmed M. Jasim ${ }^{1}$ \\ ${ }^{1}$ Ministry of Trade, Quality Control Department, Grain Board of Iraq, Al Taji/Baghdad - Iraq \\ ${ }^{*}$ Corresponding Author: Abeer S. Alhendi, Ministry of Trade, Quality Control Department, Grain Board of Iraq, \\ Al Taji/Baghdad - Iraq, e-mail: alhendiabeer@gmail.com, rdqc@grainb.iq
}

Cite as: Alhendi, A. S., Al-Rawi, S. H., \& Jasim, A. M. (2019). Effect of moisture content of two paddy varieties on the physical and cooked properties of produced rice. Brazilian Journal of Food Technology, 22, e2018184.

https://doi.org/10.1590/1981-6723.18418

\begin{abstract}
Yasemin and Anber are the main rice varieties cultivated in Iraq. Anber is the favorite variety in Iraq because of its unique flavor, and Yasemin is the most cultivated variety. Determining the suitable moisture content of both varieties to produce high extraction rate (lowest rice breakage), good rice whiteness, and the best rice quality in terms of cooked properties was the purpose of this study. Moisture content (MC) $(10 \%, 12 \%, 14 \%, 16 \%)$ of Yasemin and Anber were used, and targeted whiteness $(32,34$, and 36$)$ were obtained by using different milling times. Results showed that the best moisture content was $14 \%$ for Yasemin variety and $10 \%$ for Anber variety in terms of extraction rate. Process time increasing led to reduction of extraction rate and increased rice whiteness. The highest extraction rate of Yasemin and Anber was $56 \%$ and $64 \%$ with 32 whiteness, respectively. Kernel breakage had opposite relationship with extraction rate. Yasemin and Anber varieties were classified as short grain rice depending on their length. The maximum elongation was at $16 \% \mathrm{MC}$ for Yasemin variety and at 10\% MC for Anber variety, which increased $60 \%$ more than uncooked rice. There was no definite pattern observed for increasing rice volume (width and weight). In conclusion, the extraction rate of Yasemin and Anber varieties was increased at $14 \%$ and $10 \% \mathrm{MC}$, respectively. For cooked properties, 10\% MC of Anber was the best in terms of rice elongation, while $16 \% \mathrm{MC}$ was the best for Yasemin variety.
\end{abstract}

Keywords: Rice; Milling process; Moisture content; Extraction rate; Kernel elongation; Kernel breakage.

\section{Resumo}

Yasemin e Amber são as principais variedades de arroz cultivadas no Iraque. A variedade Amber é a favorita por causa de seu sabor único, enquanto a Yasemin é a mais cultivada. O objetivo do presente estudo foi determinar o teor de umidade adequado para ambas as variedades, na obtenção da melhor taxa de extração (menor quebra), brancura e qualidade do arroz em termos das propriedades de cozimento. Os teores de umidade (TU) $(10 \%, 12 \%$, $14 \%$ e $16 \%$ ) e a brancura-alvo (32, 34 e 36) foram empregados para as variedades Yasemin e Amber com diferentes tempos de moagem. Os resultados mostraram que o melhor TU, em relação à taxa de extração, foi de $14 \%$ para a 
variedade Yasemin e de $10 \%$ para a variedade Amber. O aumento do tempo do processo levou à redução da taxa de extração e ao aumento da brancura do arroz. As maiores taxas de extração foram de $56 \%$ e $64 \%$ para as variedades Yasemin e Amber, respectivamente, com 32 de brancura. A quebra do grão teve relação oposta à taxa de extração. As variedades Yasemin e Amber, quanto ao comprimento, foram classificadas como arrozes de grão curto. O alongamento máximo, de $60 \%$ com relação ao arroz cru, foi obtido com TU de $16 \%$ para variedade Yasemin e de $10 \%$ para variedade Amber. Não houve padrão definido para o aumento do volume de arroz (largura e peso). Em conclusão, as taxas de extração das variedades Yasemin e Amber foram maiores em TU de 14\% e 10\%, respectivamente. Para as propriedades de cozimento, em termos do alongamento do arroz, o TU de $10 \%$ para a variedade Amber foi a melhor condição, enquanto para a variedade Yasemin foi de $16 \%$.

Palavras-chave: Arroz; Processo de moagem; Teor de umidade; Taxa de extração; Alongamento do grão; Quebra do grão.

\section{Introduction}

Rice (Oryza sativa L.) is one of the most important crops beside wheat and maize (Shewry et al., 2002). Rice is the main food for more than half of the world population. Approximately $90 \%$ of the rice production occurs in tropical/sub-tropical Asia where $60 \%$ of the world population lives (Sridevi \& Chellamuthu, 2015). Iraq government via Grain Board of Iraq (GBI) imported 696.000, 366.000, and 217.000 ton (Alhendi \& Mohammed, 2018) in addition to domestic paddy rice 200.000, 43.000, and 100.000 ton during 2015, 2016, and 2017, respectively, to distribute a monthly ration to Iraqi people (Data from GBI). Ghadge \& Prasad (2012) mentioned that $75 \%$ of the daily taken calories of Asian people were from rice. The properties of the produced rice are different depending on rice variety, cultivation methods, paddy processing, and cooking conditions (Roy et al., 2011). The marketing value of rice depends on its physical quality. The percentage of the whole rice (head rice) is considered the most important feature of the produced rice (Ghadge \& Prasad, 2012). The market value of the broken rice is half the value of the head rice ( $75 \%$ to $100 \%$ of the whole kernel) (Corrêa et al., 2007). Kernel breakage of rice during milling is one of the main problems in rice industry due to the cooking quality of the produced rice and consequently the market value of the rice (Alizadeh et al., 2011). Most breakage in rice occurs because of the grains fissuring before milling, which is caused because of readsorption of moisture by low-moisture grains. Harvesting paddy with high moisture content and controlling drying process play an important role of fissured paddy and consequentially breakage of rice (Kunze, 2008). Most kernel breakage occurs at the beginning of paddy processing; however, some authors mentioned that extending the milling process leads to a high temperature that rises the rice breakage (Buggenhout et al., 2013). For cooking properties, greater length elongation, less volume extension, and less water absorption have been related to high rice quality (Ge et al., 2005).

Anber is the best rice variety cultivated in Iraq because of its unique flavor, while Yasemin is the most commonly cultivated variety in Iraq, which present $97 \%, 99 \%$, and $78 \%$ of cultivated rice in Iraq during 2015, 2016, and 2017 respectively (Data from GBI). Therefore, the current study considered these two varieties to determine the optimum moisture content of paddy to produce the best rice quality in terms of high extraction rate, rice breakage reduction, rice whiteness increasing, and cooking quality enhancement. These are the main parameters in terms of good milling quality (Furahisha et al., 2016), and milling quality improvement is a continuing goal for the rice specialists in the country. 


\section{Material and methods}

\subsection{Paddy preparation for milling}

Two paddy varieties namely Anber and Yasemin were obtained from Al-Najaf and Babel (two Iraqi provinces) silos during 2017 harvesting season. They have been cleaned from impurities by using a sieve with $2.58 \mathrm{~mm}$ diameter. Samples were stored at ambient temperature with the initial moisture content of $16 \%$. Four levels of moisture content $(16.0 \%, 14.0 \%, 12.0 \%$, and $10.0 \%$ w.b.) of the two varieties were reached either by dropping moisture naturally (waiting for moisture reduction) or by natural (sun) drying. Moisture content (MC) of the rice paddy was determined by using a moisture tester (Seedburo Equipment Company, Des Plaines, IL, USA) following AACC method (American Association of Cereal Chemists, 2000).

\subsection{Milling}

The cleaned paddy rice (with specific MC) was milled by using two huller machines. The first huller (SATAKE Corporation, Bangkok, Japan) removed rice husk, and the process was repeated twice to reduce the whole rice proportion in the produced rice. Dehulled rice $(100 \mathrm{~g})$ obtained from the first huller machines was placed in the second huller machine (Mitsubishi Electric Automation, Thailand) for $33 \mathrm{~s}$ to $48 \mathrm{~s}$ depending on the rice MC and the paddy variety to obtain the required whitening, which was set to be 32,34 , and 36. The lowest whiteness permissible limit according to the rules and regulations for the paddy rice manufacturing in public and private milling for the season 2016/2017 was 32 (Data from GBI). The second huller was cleaned after every two runs to obtain a suitable friction that gives a constant whiteness with the same process properties.

\subsection{Physical properties of the produced rice}

\subsubsection{Rice whiteness}

Rice whiteness was determined by using a rice whiteness tester (Rice whiteness Tester C-600, Kett Electric Laboratory, Tokyo, Japan) after calibration with a whiteness standard plate at 84.9 whiteness.

\subsubsection{Extraction rate}

The extraction rate of each treatment was calculated by weighing the produced head rice to the amount of the origin paddy used. The Equation 1 below expresses the calculation.

Extraction rate $=\frac{\text { Head rice } g}{\text { paddy } g} \times 100$

\subsubsection{Breakage of rice kernels}

Broken rice was separated by placing a specific amount of the processed rice in the rice grader (Satake Testing Rice Grader, Satake Australia, Penrith, NSW, 2750, Australia) to separate the whole rice from the broken rice. Then the broken percentage was calculated by dividing the broken weight by the whole sample weight multiplying by 100 .

\subsubsection{Cooked rice}

Cooked rice properties were detected according to Tian et al. (2005) study. Ten intact uncooked rice kernels were selected randomly from each process line and measured for weight, length (kernels were placed 
as one line), and width (kernels were placed side by side). Then, the selected kernels were soaked into distilled water for $30 \mathrm{~min}$ and placed between two wet filter papers in a petri dish above boiling water for $20 \mathrm{~min}$. The cooked rice was transferred to a dry filter paper inside a dry petri dish, placed in a desiccator for about $15 \mathrm{~min}$ to remove the adhered water. The desiccated cooked rice kernels were measured for length, width and weight similarly to before cooking.

\subsection{Statistical analysis}

Statistical analysis was performed using two-way analysis of variance (ANOVA) (Two-Factors with Replication) with SAS version 9.0 (SAS Institute INC., SAS Campus Drive, Cary, NC, USA) and Least Significant Difference (LSD) for comparison of means. Differences were considered significant at $\alpha=0.05$. All experiments were conducted in duplicate.

\section{Results}

\subsection{Physical properties of produced rice}

Table 1 shows the required time of each variety with different moisture content to produce different rice whiteness. The higher the moisture content, the higher the process time required to obtain a specific rice whiteness. Yasemin variety $(10 \% \mathrm{MC})$ required the lowest treatment time to obtain the required whiteness, which was 32, 34, and 36 compared to Yasemin variety with different MC. Table 2 explains the extraction rate of produced rice with different moisture contents and with different whiteness. The extraction rate of Yasemin was between $48 \%$ and $56 \%$ for 32 rice whiteness and between $44 \%$ and $54 \%$ for 36 rice whiteness. While the extraction rate of Anber was higher than Yasemin, which was between $53 \%$ and $64 \%$ for 32 rice whiteness and between $49 \%$ and $60 \%$ for 36 rice whiteness. Extraction rate generally reduces with high rice whiteness. For Yasemin, the highest extraction rate was for paddy with $14 \% \mathrm{MC}$ followed by $12 \% \mathrm{MC}$ for the rice whiteness 32 and 34 . The lowest extraction rate was at $10 \% \mathrm{MC}$ for Yasemin. The opposite was for Anber, which had the highest extraction rate with $10 \% \mathrm{MC}$ for all rice whiteness followed by $14 \% \mathrm{MC}$. Table 3 presents kernel breakage of produced rice with different rice whiteness and different moisture content. Kernel breakage increased with high rice whiteness; however, for some treatments breakage values were almost stable such as for Anber variety with $12 \%$ and $16 \% \mathrm{MC}$. The highest kernel breakage percentage was with $10 \% \mathrm{MC}$ of Yasemin and 14\% MC of Anber. The lowest kernel breakage was with 14\% MC of Yasemin and 10\% MC of Anber, which were the highest extraction rate treatments.

Table 1. Required time for each treatment to obtain 32, 34, and 36 whiteness of Yasemin and Anber varieties with different MC.

\begin{tabular}{|c|c|c|c|c|c|c|c|c|}
\hline \multirow{3}{*}{ Time (s) } & \multicolumn{4}{|c|}{ Yasemin } & \multicolumn{4}{|c|}{ Anber } \\
\hline & \multicolumn{4}{|c|}{ Moisture content ( $\%)$} & \multicolumn{4}{|c|}{ Moisture content $(\%)$} \\
\hline & 10 & 12 & 14 & 16 & 10 & 12 & 14 & 16 \\
\hline 33 & $32.3 \pm 0.2$ & - & - & - & - & - & - & - \\
\hline 36 & - & $32.0 \pm 0.0$ & $31.9 \pm 0.1$ & - & $32.0 \pm 1.0$ & $31.9 \pm 0.1$ & $32.2 \pm 0.5$ & - \\
\hline 39 & $33.8 \pm 0.3$ & - & - & - & - & - & - & $31.75 \pm 0.4$ \\
\hline 42 & - & $33.8 \pm 0.3$ & $34.1 \pm 0.6$ & $31.9 \pm 0.4$ & $34.6 \pm 0.2$ & $33.8 \pm 0.4$ & $33.9 \pm 0.4$ & $34.0 \pm 0.1$ \\
\hline 45 & $36.3 \pm 0.6$ & - & - & $33.5 \pm 0.5$ & $36.5 \pm 0.6$ & $36.6 \pm 0.1$ & - & - \\
\hline 48 & - & $36.3 \pm 0.4$ & $36.0 \pm 0.1$ & $36.2 \pm 0.5$ & - & - & $36.5 \pm 0.1$ & $36.0 \pm 0.0$ \\
\hline
\end{tabular}


Table 2. Extraction rate of produced rice with different MC and different whiteness of Yasemin and Anber varieties.

\begin{tabular}{|c|c|c|c|c|c|c|c|c|}
\hline \multirow{3}{*}{ Whitens } & \multicolumn{4}{|c|}{ Yasemin } & \multicolumn{4}{|c|}{ Anber } \\
\hline & \multicolumn{4}{|c|}{ Moisture content (\%) } & \multicolumn{4}{|c|}{ Moisture content (\%) } \\
\hline & 10 & 12 & 14 & 16 & 10 & 12 & 14 & 16 \\
\hline 32 & $48.0 \pm 1.1 \mathrm{Aa}$ & $53.9 \pm 7.8 \mathrm{Aa}$ & $56.1 \pm 2.9 \mathrm{Aa}$ & $44.4 \pm 0.2 \mathrm{Aa}$ & $63.8 \pm 0.7 \mathrm{Aa}$ & $53.0 \pm 3.3 \mathrm{Aab}$ & $56.1 \pm 2.9 \mathrm{Aab}$ & $49.8 \pm 0.7 \mathrm{Ab}$ \\
\hline 34 & $48.8 \pm 0.6 \mathrm{Aa}$ & $54.6 \pm 7.9 \mathrm{Aa}$ & $54.1 \pm 1.6 \mathrm{Aa}$ & $48.9 \pm 0.3 \mathrm{Aa}$ & $62.8 \pm 0.7 \mathrm{Aa}$ & $51.2 \pm 3.9 \mathrm{Ab}$ & $54.1 \pm 1.6 \mathrm{Aab}$ & $50.8 \pm 0.4 \mathrm{Ab}$ \\
\hline 36 & $45.7 \pm 0.8 \mathrm{Aa}$ & $44.7 \pm 1.7 \mathrm{Aa}$ & $53.8 \pm 1.0 \mathrm{Aa}$ & $51.4 \pm 3.4 \mathrm{Aa}$ & $60.4 \pm 1.7 \mathrm{Aa}$ & $49.3 \pm 2.1 \mathrm{Ab}$ & $53.8 \pm 1.0 \mathrm{Aab}$ & $53.2 \pm 1.9 \mathrm{Aab}$ \\
\hline
\end{tabular}

Values expressed as a mean \pm S.D. Means with a different capital letter within the same column are significantly different, and with different small letters within the same row and same variety are significantly different at $p<0.05$.

Table 3. Kernel breakage percentage of produced rice with different MC and different whiteness for Yasemin and Anber varieties.

\begin{tabular}{|c|c|c|c|c|c|c|c|c|}
\hline \multirow{3}{*}{ Whitens } & \multicolumn{4}{|c|}{ Yasemin } & \multicolumn{4}{|c|}{ Anber } \\
\hline & \multicolumn{4}{|c|}{ Moisture content (\%) } & \multicolumn{4}{|c|}{ Moisture content (\%) } \\
\hline & 10 & 12 & 14 & 16 & 10 & 12 & 14 & 16 \\
\hline 32 & $22.9 \pm 1.1 \mathrm{ABa}$ & $17.0 \pm 7.8 \mathrm{Bb}$ & $14.9 \pm 2.9 \mathrm{Ab}$ & $17.4 \pm 0.2 \mathrm{Ab}$ & $14.5 \pm 0.7 \mathrm{Bc}$ & $17.5 \pm 3.3 \mathrm{Ab}$ & $22.5 \pm 2.9 \mathrm{Ba}$ & $17.3 \pm 0.7 \mathrm{Ab}$ \\
\hline 34 & $21.3 \pm 0.6 \mathrm{Ba}$ & $15.5 \pm 7.9 \mathrm{Bb}$ & $16.0 \pm 1.6 \mathrm{Ab}$ & $18.3 \pm 0.3 \mathrm{Aab}$ & $15.5 \pm 0.7 \mathrm{Bc}$ & $17.9 \pm 3.9 \mathrm{Ab}$ & $22.0 \pm 1.6 \mathrm{Ba}$ & $18.3 \pm 0.4 \mathrm{Ab}$ \\
\hline 36 & $26.0 \pm 0.8 \mathrm{Aa}$ & $23.9 \pm 1.7 \mathrm{Aab}$ & $16.0 \pm 1.0 \mathrm{Ac}$ & $21.4 \pm 3.4 \mathrm{Ab}$ & $18.0 \pm 1.7 \mathrm{Ab}$ & $19.0 \pm 2.1 \mathrm{Ab}$ & $26.5 \pm 1.0 \mathrm{Aa}$ & $18.5 \pm 1.9 \mathrm{Ab}$ \\
\hline
\end{tabular}

Values expressed as a mean \pm S.D. Means with a different capital letter within the same column are significantly different, and with different small letters within the same row and same variety are significantly different at $p<0.05$. 


\subsection{Cooking properties of produced rice}

Figure 1 demonstrates kernel length of rice grains before cooking and the length increment after cooking. There were no significant differences between kernel length before cooking of each variety with different whiteness and different moisture content. Yasemin and Anber have approximately the same length, around $6 \mathrm{~mm}$. Length increment of Yasemin varied; however, the highest increment occurred with high moisture content. For Anber, the highest increment occurred with $10 \% \mathrm{MC}$ followed by $16 \% \mathrm{MC}$. Figure 2 expresses rice width of 10 rice kernels; rice width was between $2.2 \mathrm{~mm}$ and $2.6 \mathrm{~mm}$ for Yasemin variety and between 2.0 and $2.6 \mathrm{~mm}$ for Anber variety. The increment in rice width was between $11 \%$ and $47 \%$ for Yasemin variety and between $2 \%$ and $40 \%$ for Anber variety. There were significant differences between rice width before cooking and for the increment after cooking for both varieties (Figure 2). Figure 3 shows 10 rice kernels weight before cooking and increment after cooking. The weight increment generally varied; however, the lowest increment of Yasemin variety was with $10 \% \mathrm{MC}$, while the highest increment was with $16 \% \mathrm{MC}$ and some with 14\% MC. For Anber variety, the highest increment mostly occurred with $10 \% \mathrm{MC}$ followed by $16 \% \mathrm{MC}$.

\section{Discussions}

\subsection{Physical properties}

In some countries, rice whiteness is one of the main characteristics of produced rice, while for other countries this is not considered like that. In Iraq, rice whiteness is an important trait as well as in Iran (Alizadeh, 2011). 

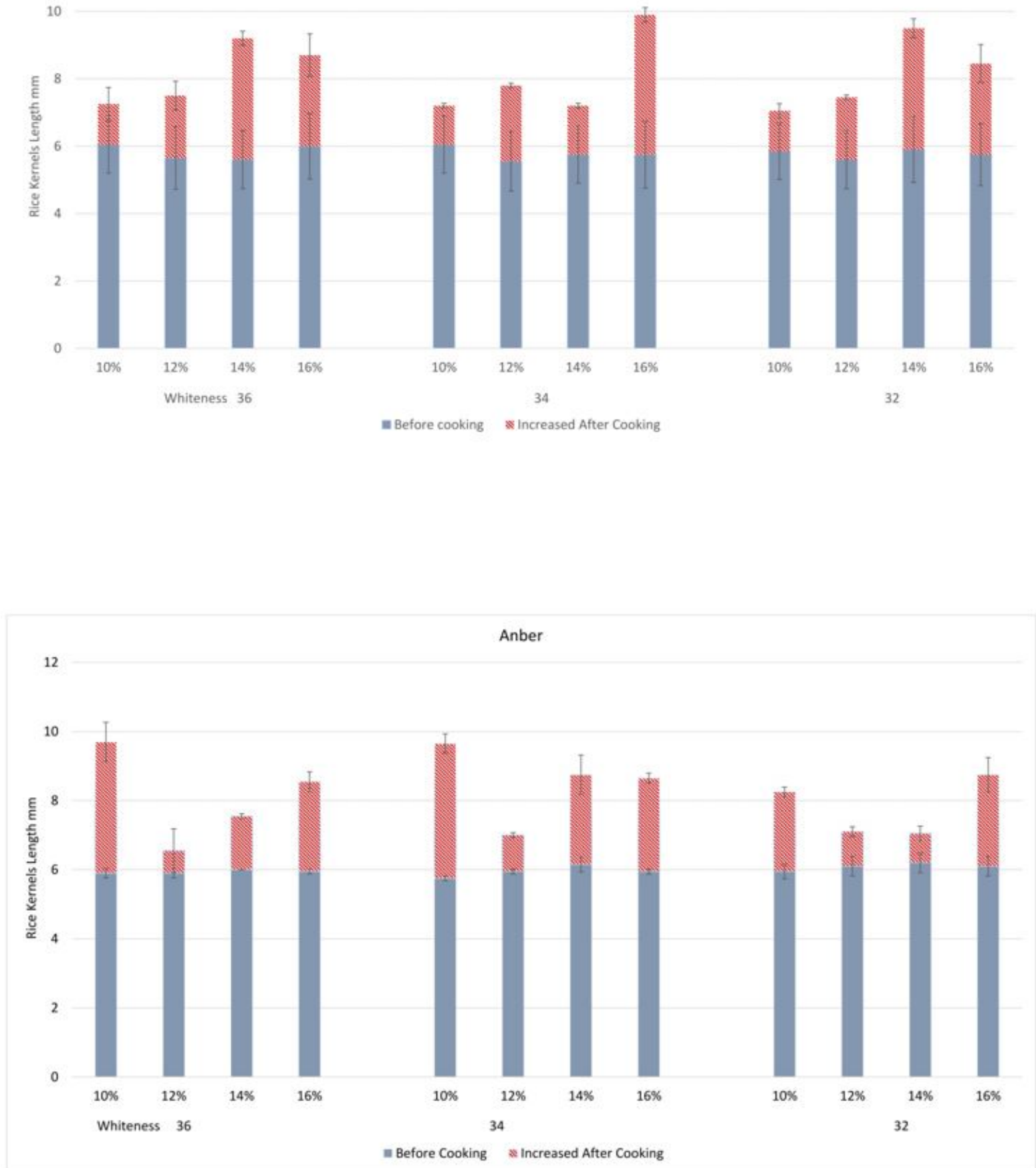

Figure 1. Kernels length $(\mathrm{mm})$ of produced rice before cooking and length increment after cooking for Yasemin and Anber varieties with different MC and different whiteness. 

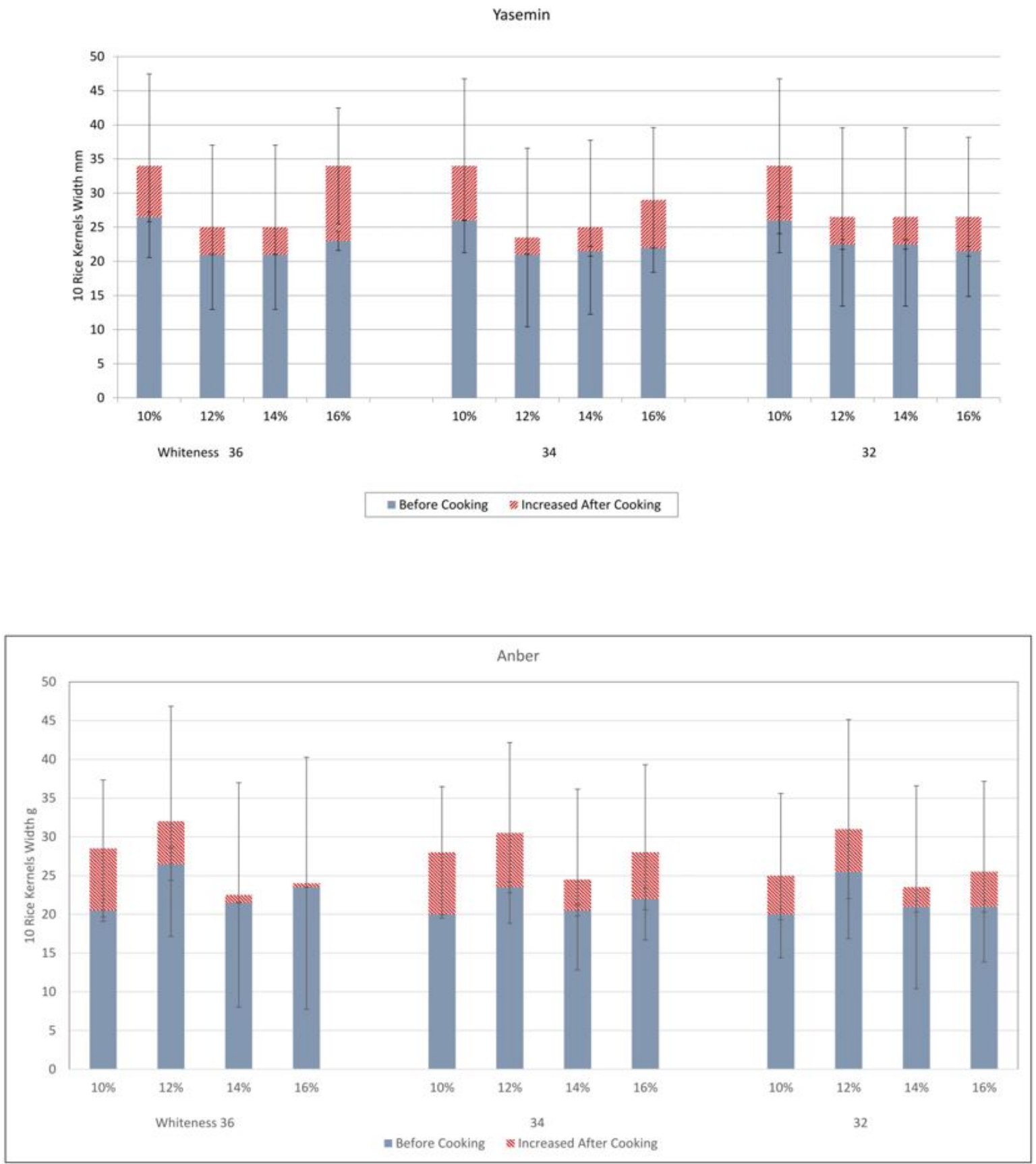

Figure 2. 10 kernels width $(\mathrm{mm})$ of produced rice before cooking and the increment of width after cooking for Yasemin and Anber varieties with different MC and different whiteness. 

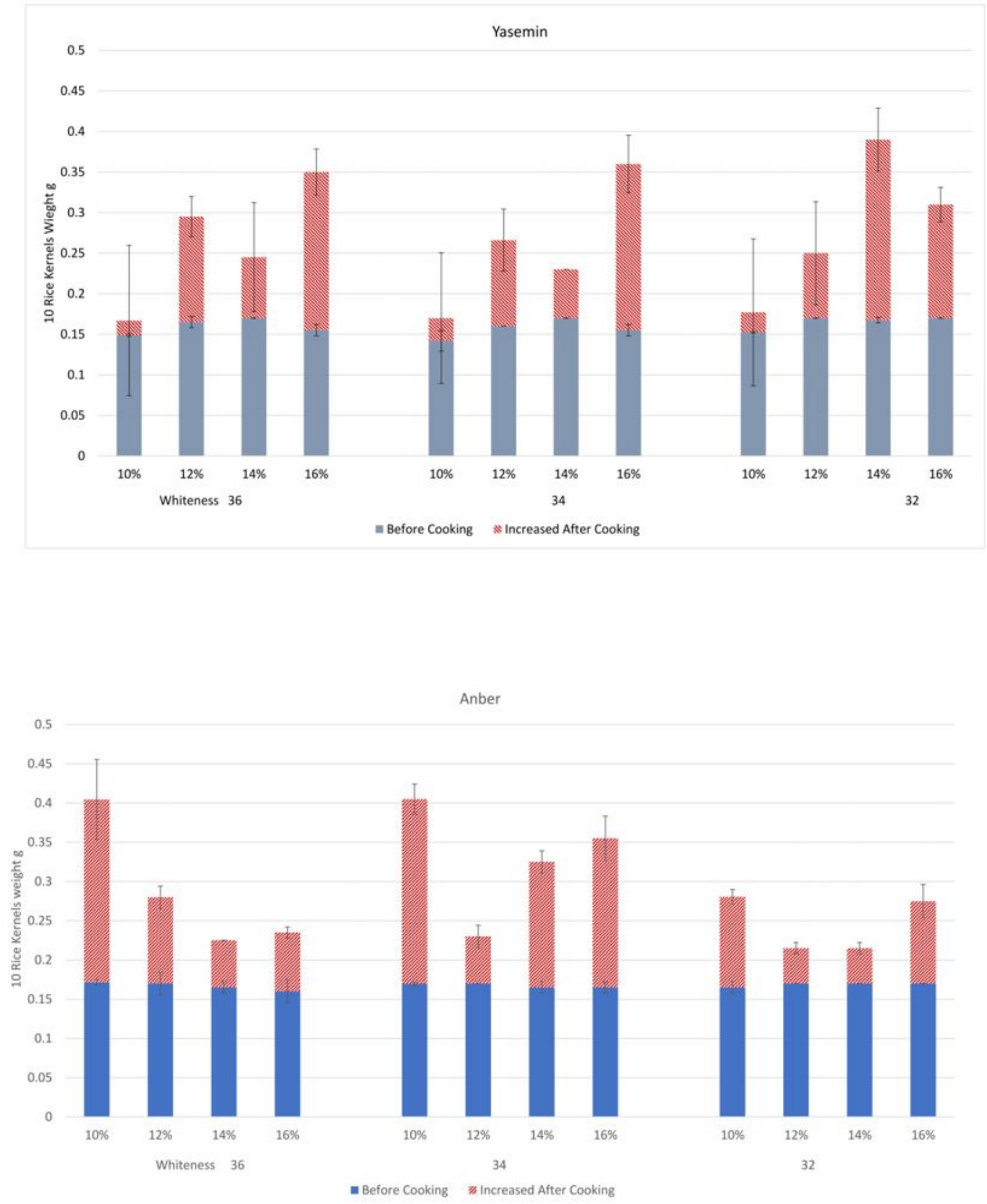

Figure 3. 10 kernels weight $(\mathrm{g})$ of produced rice before cooking and the increment of weight after cooking for Yasemin and Anber varieties with different MC and different whiteness.

Rice whiteness increases with extending the degree of milling (DOM), which depends on rice variety (Billiris et al., 2012). Yasemin variety required less time to produce whiteness compared to Anber. Rice whiteness depends on some parameters such as chalkiness, size, and shape. Furahisha et al. (2016) mentioned that the whiteness index varied among cultivars due to unique chemical and physical properties, which affects milling features. The lowest acceptable whiteness in the rice industry in Iraq is 32 (GBI); however, higher rice whiteness is preferred by Middle East people (Lyon et al., 1999). Champagne et al. (1999) mentioned that $40 \pm 2$ was the target whiteness considered as typical of regular milled rice. Paddy with lower moisture 
content needed less process time to obtain the exact whiteness compared with high moisture content (Table 1) and that is probably because the higher moisture content, the less friction occurred, which leads to increase the required time to obtain exact whiteness. Process time increasing leads to process cost increasing, which is higher with high MC of process paddy. Buggenhout et al. (2013) mentioned that process time increasing causes a high percent of rice breakage due to high temperature, but this does not agree with the result of this study for Yasemin variety, in which kernel breakage was higher with the lowest treatment time (lowest MC, $10 \%)$.

Extraction rate increasing of whole rice (head rice) is a fundamental aim in rice industry (Banasek \& Siebenmorgen, 1990). Producing high whiteness rice causes extraction rate lowering because of more bran layers removal. In addition, high whiteness needs more process time, leading to kernel breakage increasing, which reduces the extraction rate. The extraction rate had a negative correlation with the percent of kernel breakage (Table 2 and 3); the higher extraction rates, the lesser kernel breakage detected. The extraction rate range of the two varieties with different moisture content was between $44 \%$ and $63 \%$, and it was higher than the extraction rate mentioned by Sanusi et al. (2017), which was between $13 \%$ and $48 \%$ for four different varieties. While in the Rather et al. (2016) study the head rice percentage was between $66 \%$ and $68 \%$. The highest extraction rate of Yasemin was with 14\% MC (Table 2) and the lowest kernel breakage was with $14 \%$ MC (Table 3). However, Perdon et al. (2000) reported that moisture content of harvested paddy must be reduced to about $12 \%$ for safe storage purposes. While the highest extraction rate and lowest kernel breakage of Anber variety were with 10\%. Furahisha et al. (2016) reported that $12 \% \mathrm{MC}$ was to achieve the highest total rice yield. Moisture content causes differential stress inside the rice kernel that causes significant kernel fissure (Cnossen \& Siebenmorgen, 2000). Rice breakage usually occurs due to harvesting, drying, dehulling, and milling when the applied forces exceed the grain strength. Therefore, the process intensity controls the broken rice percentage in addition to fissures, chalkiness, immaturity, and rice kernel dimensions (Buggenhout et al., 2013).

\subsection{Cooking properties}

People from different areas of the world prefer different sensory properties of rice. For example, in Middle East people prefer long, firm and non-sticky cooked rice; U.S. consumers prefer medium and long grain rice, while Japanese people prefer short and sticky rice (Lyon et al., 1999). Rice variety is one of the main features that affect the quality of produced rice due to the fundamental characteristics of each variety. One of the rice classifications depends on the length of the kernel. Long grain rice should be equal or more than $6.6 \mathrm{~mm}$, medium grain rice should be equal or more than $6.2 \mathrm{~mm}$, and less than $6.2 \mathrm{~mm}$ is considered short grain rice (Food and Agriculture Organization of the United Nations, 1995). Depending on this classification, Yasemin and Ander varieties are short grain rice. The longest grain was $6.2 \mathrm{~mm}$ of Anber variety, obtained from 14\% $\mathrm{MC}$ with 32 whiteness. For Yasemin variety, the longest grain was $6.05 \mathrm{~mm}$. Rice length increasing after cooking is also considered a quality parameter of the produced rice (Ge et al., 2005). Basmati 370, a famous variety, has more than $100 \%$ increase in length with a little increase in width after cooking (Tian et al., 2005). The elongation of produced rice was variable; the highest elongation was about $60 \%$ and that mostly occurs with $14 \% \mathrm{MC}$ and $16 \% \mathrm{MC}$ of Yasemin variety and 10\% MC of Anber variety. These results agreed with the Rather et al. (2016) study, in which the rice elongation of three studied varieties was between $60 \%$ and $70 \%$. The $14 \%$ and $10 \% \mathrm{MC}$ treatment of Yasemin and Anber respectively were the best treatments in terms of high extraction rate and lower percent of broken kernel. The lowest elongation was $20 \%$ or less that occurred with 10\% MC and 12\% MC of Yasemin and Anber respectively. Tian et al. (2005) mentioned that elongation of different rice varieties was between $<30 \%$ and $>130 \%$. The elongation of Yasemin and Anber is within the middle and lower percentage of the Tian et al. (2005) study.

Weng et al. (2008) reported that rice width of 46 rice cultivars was between $2.4 \mathrm{~mm}$ and $3.5 \mathrm{~mm}$ depending on the cultivars genetic. The rice width of Yasemin and Anber varieties were mostly lower than $2.4 \mathrm{~mm}$; 
however, the largest width was $2.6 \mathrm{~mm}$ for both varieties. High extension of rice volume after cooking is one of an unwanted features of a good quality rice (Ge et al., 2005). The increment of Anber variety was less than Yasemin variety and, in both varieties, the highest width extension was less than $50 \%$ of the original width (Figure 2). The highest increment occurred with $10 \%$ and $12 \% \mathrm{MC}$ of Anber variety and with $10 \% \mathrm{MC}$ of Yasemin variety in addition to some $16 \% \mathrm{MC}$ treatments.

Increasing of rice weight after cooking refers to water absorption. The lesser the water absorption of cooked rice, the higher the rice quality (Ge et al., 2005). The weight range increasing mentioned by Perdon et al. (1997) was between about $50 \%$ and $210 \%$ of the initial rice weight depending on the moisture content of raw rice, rice storage period, and temperature of rice during storage. This range of weight increment of Yasemin was between $12 \%$ and $123 \%$ and for Anber was between $26 \%$ and $138 \%$ (Figure 3). The maximum weight increment of Yasemin variety was mostly with high MC (14\% and 16\%) of raw rice, while for Anber variety was with low MC (10\%). Perdon et al. (1997) mentioned that the highest weight increment was with $8.8 \% \mathrm{MC}$ and $13.6 \% \mathrm{MC}$ at $30{ }^{\circ} \mathrm{C}$.

\section{Conclusion}

According to their length, Yasemin and Anber varieties were classified as short grain rice. Extraction rate and kernel breakage of Yasemin and Anber varieties could be improved by using an appropriate moisture content during rice processing. 14\% MC and 10\% MC of Yasemin and Anber respectively were the best MC in terms of producing high extraction rate, lower kernel breakage, and high rice elongation. Increasing the required rice whiteness reduces the extraction rate. The initial moisture content of paddy had an effect on the cooking properties of the produced rice.

\section{Acknowledgements}

The authors are thankful to Grain Board of Iraq for covering all the study costs.

\section{References}

Alhendi, A. S., \& Mohammed, H. E. (2018). Microbiological quality of wheat cultivated in many different regions of Iraq. Iraqi Journal of Science, 59(2A), 654-659.

Alizadeh, M. R. (2011). Effect of paddy husked ratio on rice breakage and whiteness during milling process. Australian Journal of Crop Science, 5(5), 562.

Alizadeh, M. R., Dabbaghi, A., \& Rahimi-Ajdadi, F. (2011). Effect of final paddy moisture content on breaking force and milling properties of rice varieties. Elixir Agriculture, 36, 3186-3189.

American Association of Cereal Chemists. American Association of Cereal Chemists - AACC. (2000). Approved methods of the AACC (10th ed.). Saint Paul: AACC.

Banasek, M. M., \& Siebenmorgen, T. J. (1990). Adsorption equilibrium moisture contents of long-grain rough rice. American Society of Agricultural Engineers, 33(1), 247-252. http://dx.doi.org/10.13031/2013.31323

Billiris, M. A., Siebenmorgen, T. J., Meullenet, J. F., \& Mauromoustakos, A. (2012). Rice degree of milling effects on hydration, texture, sensory and energy characteristics. Part 1: Cooking using excess water. Journal of Food Engineering, 113(4), 559-568. http://dx.doi.org/10.1016/j.jfoodeng.2012.07.005

Buggenhout, J., Brijs, K., Celus, I., \& Delcour, J. A. (2013). The breakage susceptibility of raw and parboiled rice: A review. Journal of Food Engineering, 117(3), 304-315. http://dx.doi.org/10.1016/j.jfoodeng.2013.03.009

Champagne, E. T., Bett, K. L., Vinyard, B. T., McClung, A. M., Barton 2nd, F. E., Moldenhauer, K., Linscombe, S., \& McKenzie, K. (1999). Correlation between cooked rice texture and rapid visco analyser measurements. Cereal Chemistry, 76(5), 764-771. http://dx.doi.org/10.1094/CCHEM.1999.76.5.764

Cnossen, A. G., \& Siebenmorgen, T. J. (2000). The glass transition temperature concept in rice drying and tempering: Effect on milling quality. Transactions of the ASAE, 43(6), 1661-1667. http://dx.doi.org/10.13031/2013.3066

Corrêa, P. C., Silva, F. S., Jaren, C., Afonso, P. C., \& Arana, I. (2007). Physical and mechanical properties in rice processing. Journal of Food Engineering, 79(1), 137-142. http://dx.doi.org/10.1016/j.jfoodeng.2006.01.037

Food and Agriculture Organization of the United Nations - FAO. (1995). Codex standard for rice (Codex Stan 198-1995). Rome: FAO. $6 \mathrm{p}$. 
Furahisha, K., Chove, L. M., \& Chaula, D. (2016). Effect of final moisture content, cooling time and paddy variety on milling quality of rice (Oryza sativa, L.). Journal of Agricultural Science and Food Technology, 2(11), 169-179.

Ge, X. J., Xing, Y. Z., Xu, C. G., \& He, Y. Q. (2005). QTL analysis of cooked rice grain elongation, volume expansion, and water absorption using a recombinant inbred population. Plant Breeding, 124(2), 121-126. http://dx.doi.org/10.1111/j.14390523.2004.01055.x

Ghadge, P. N., \& Prasad, K. (2012). Some physical properties of rice kernels: Variety PR-106. Journal of Food Processing \& Technology, 3(8), 1-5. http://dx.doi.org/10.4172/2157-7110.1000175

Kunze, O. R. (2008). Effect of drying on grain quality: Moisture readsorption causes fissured rice grains. Agricultural Engineering International Journal, $X(1), 1-17$.

Lyon, B. G., Champagne, E. T., Vinyard, B. T., Windham, W. R., Barton 2nd, F. E., Webb, B. D., McClung, A. M., Moldenhauer, K. A., Linscombe, S., McKenzie, K. S., \& Kohlwey, D. E. (1999). Effects of degree of milling, drying condition, and final moisture content on sensory texture of cooked rice. Cereal Chemistry, 76(1), 56-62. http://dx.doi.org/10.1094/CCHEM.1999.76.1.56

Perdon, A. A., Marks, B. P., Siebenmorgen, T. J., \& Reid, N. B. (1997). Effects of rough rice storage conditions on the amylograph and cooking properties of medium-grain rice cv. Bengal. Cereal Chemistry, 74(6), 864-867. http://dx.doi.org/10.1094/CCHEM.1997.74.6.864

Perdon, A., Siebenmorgen, T. J., \& Mauromoustakos, A. (2000). Glassy state transition and rice drying: development of a brown rice state diagram. Cereal Chemistry, 77(6), 708-713. http://dx.doi.org/10.1094/CCHEM.2000.77.6.708

Rather, T. A., Malik, M. A., \& Dar, A. H. (2016). Physical, milling, cooking, and pasting characteristics of different rice varieties grown in the valley of Kashmir India. Cogent Food \& Agriculture, 2(1), 1178694. http://dx.doi.org/10.1080/23311932.2016.1178694

Roy, P., Orikasa, T., Okadome, H., Nakamura, N., \& Shiina, T. (2011). Processing conditions, rice properties, health and environment. International Journal of Environmental Research and Public Health, 8(6), 1957-1976. PMid:21776212. http://dx.doi.org/10.3390/ijerph8061957

Sanusi, M. S., Akinoso, R., \& Danbaba, N. (2017). Evaluation of physical, milling and cooking properties of four new rice (Oryza sativa L.) varieties in Nigeria. International Journal of Food Studies, 6(2), 245-256. http://dx.doi.org/10.7455/ijfs/6.2.2017.a10.

Shewry, P. R., Halford, N. G., Belton, P. S., \& Tatham, A. S. (2002). The structure and properties of gluten: An elastic protein from wheat grain. Philosophical Transactions of the Royal Society of London. Series B, Biological Sciences, 357(1418), 133142. PMid:11911770. http://dx.doi.org/10.1098/rstb.2001.1024

Sridevi, V., \& Chellamuthu, V. (2015). Impact of weather on rice: A review. International Journal of Applied Research, 1(9), 825831.

Tian, R., Jiang, G. H., Shen, L. H., Wang, L. Q., \& He, Y. Q. (2005). Mapping quantitative trait loci underlying the cooking and eating quality of rice using a DH population. Molecular Breeding, 15(2), 117-124. http://dx.doi.org/10.1007/s11032-004-3270-z

Weng, J., Gu, S., Wan, X., Gao, H., Guo, T., Su, N., Lei, C., Zhang, Z., Cheng, Z., Guo, X., Wang, J., Jiang, L., Zhai, H., \& Wan, J. (2008). Isolation and initial characterization of GW5, a major QTL associated with rice grain width and weight. Cell Research, 18(12), 1199-1209. PMid:19015668. http://dx.doi.org/10.1038/cr.2008.307

Funding: Grain Board of Iraq. 